\title{
Current Issues of Involuntary Medical Intervention into the Physical Integrity of a Patient
}

\author{
Pavel Doubek \\ PhD Student, Faculty of Law, Masaryk University in Brno, Czech Republic
}

\begin{abstract}
The physical integrity of a person and a public interest are two values that are in permanent conflict. One time, the interest of society prevails, in another time it will be the interest of patient that should take precedence. In this article, I will focus on the conditions for limiting the right to physical integrity with respect to public interests and I will try to draw an appropriate line between these values.
\end{abstract}

Keywords: a physical integrity, a human dignity, a fundamental human right, eugenics, coercion, consent

\section{Introduction}

The aim of this article is to highlight the current issues of involuntary medical treatment in a view of the fundamental right to the inviolability of the physical integrity of person. The core of the article is the analysis of the ,public interests“, which justify or (in the past) justified medical intervention into the physical integrity of a patient without his consent. In the lines below, I am going to answer questions relating to so called „hard cases“"1 in medicine. One of the questions that I will try to answer is whether the eugenic, social or economic ideas relating to the treatment of a patient are the thing of the past or they are still alive.

When analysing these issues, I will also discuss related issues like the criterion of medical necessity, aspect of informed consent, coercion, paternalism in health care and others. I am going to support my ideas with case law of European Court of Human Rights, international human rights law and also with standards, reports of international monitoring bodies, as well as with other sources of international soft-law. The aim of this article is to explore, what reasons currently justify involuntary medical interventions and whether these reasons are of a therapeutic nature or rather reflect some social need. At the beginning, let me ask a basic question: „Is the patient the only one, who makes the decisions about his body and life, or even in 21 th century, the state knows better?"

\section{Right to physical integrity as a fundamental human right}

There is no doubt, that the right to physical integrity of a person is a fundamental human right. Physical and moral integrity of a person is covered by Article $8^{2}$ and Article $3^{3}$ of the European Convention on Human Rights (hereinafter referred to as ,the European Convention“), by Article 5 of the Convention for the Protection of Human Rights and Dignity of the Human Being with regard to the Application of Biology and Medicine (hereinafter referred to as ,the Oviedo Convention“), as well as by Article 17 of the Convention on the Rights of Persons with Disabilities (hereinafter referred to as ",the Convention“).

Right to physical integrity refers to the right to make free decisions about person's body and health. The ECHR states, that even minor compulsory medical intervention constitutes an interference with this right. ${ }^{4}$ Some authors suggests, that the right to physical integrity is one of the most important human rights (next to the right to life and the right not to be subjected to torture or to inhuman or degrading treatment or punishment) and disrespect to this right can be seen as disrespect to a human dignity. Ahron Barak in his excellent book Human Dignity considers the physical and moral integrity of a person as essential element of human dignity. ${ }^{5}$ Barak argues, that ,the dignity of a human being is his free will; the freedom to shape his life and fulfil himself. It is a person's freedom to write his life story. At the core of a person's humanity stands the autonomy of her will, which means that person herself-she, and no one else-determines her destiny. " 6

There is no doubt, that the right to physical integrity occupies very important position in the system of fundamental human rights and basic freedoms ${ }^{7}$ and that the arbitrary breach of this right can violate the human dignity and lead to degrading and inhuman treatment. ${ }^{8}$ 


\section{Limitation of the right to physical integrity}

Despite of its high importance, the right to physical integrity of a person is not absolute. According to the Article 26 of the Oviedo Convention it is possible to break the general rule of free and informed consent enshrined in Article $5^{9}$. However, the measure limiting fundamental right must be ,prescribed by law and necessary in a democratic society in the interest of public safety, for the prevention of crime, for the protection of public health or for the protection of the rights and freedoms of others. "

According to Article 8 paragraph 2 of the European convention, the right to respect for private life can be limited, if this measure is ,,in accordance with the law and necessary in a democratic society in the interests of national security, public safety or the economic well-being of the country, for the prevention of disorder or crime, for the protection of health or morals, or for the protection of the rights and freedoms of others. "

To sum up, the European Convention and the Oviedo Convention sets forth three conditions for limiting the right to physical integrity. Limitation 1) must be in accordance with the law, 2) must pursue a legitimate aim and 3 ) must be necessary in a democratic society.

\section{Legitimate aim}

Although the above mentioned conventions set forth several legitimate aims, the international soft-law and the case law of the ECHR shows, that only two legitimate aim justify involuntary intervention into the physical integrity of a person: a protection of health of a patient himself and a protection of health of the others.

First of all, I have to stress, that the more vulnerable person is, the more strict the reasons (and conditions) for involuntary interventions are. Vulnerability refers for example to the state of health of a person (elderly people, people with disabilities, etc.), to dependency on care (patients in hospitals) or on a facility, where individuals are locked up (prisoners in a prison, migrants in a migrant detention facility, etc.). ${ }^{10}$ The Oviedo Convention in Article 7 sets forth that "a person who has a mental disorder of a serious nature may be subjected, without his or her consent, to an intervention aimed at treating his or her mental disorder only where, without such treatment, serious harm is likely to result to his or her health."

The UN Principles for the Protection of Persons with Mental Illness (hereinafter referred to as "the MI Principles") contain rules on non-consensual treatment in principle 11. The Committee on Economic, Social and Cultural Rights in General Comment No. 14: The Right to the Highest Attainable Standard of Health (Art. 12) states, that State has an obligation to respect the right to health, which includes a ,state's obligation to refrain from ... applying coercive medical treatments, unless on an exceptional basis for the treatment of mental illness or the prevention and control of communicable diseases. " 11

The CPT Standards does not expressly state, whether it is acceptable to impose involuntary treatment on patient in order to protect others, or not. However CPT sets forth a general principle that ,, any derogation from this fundamental principle (right to be treated with free and informed consent) should be based upon law and only relates to clearly and strictly defined exceptional circumstances. " 12

Hippocratic Oath sets forth two important principles that should be mentioned at this point: The principle "above all do no harm" (primum non nocere) and the principle of beneficence: "I will use those dietary regimens which will benefit my patients... and I will do no harm or injustice to them." 13 Herring states, that "the importance of the non-maleficience principle is that it urges against harming one patient to help another." 14 The principle of beneficence means that the "medical professionals must do good for their patients. They must cure any disease or injury where possible and avoid the infliction of pain where possible." 15 Concurrently, the physician must respect the autonomous decision of his patient. Physicians therefore have to treat the patient in order to cure his disease and concurrently be his partners, who will discuss his medical issues with him. The physician has to use all his knowledge and experience while treating his patient, but he is not allowed to act in a paternal manner. ${ }^{16}$

To sum up, the legitimate aim for the interference into the physical integrity of a person should be the protection of the health of the patient or the health of other people. But are there any other legitimate aims? Should physician treat a patient in order to save public expenses? Should state orders an interruption for a pregnant mentally disabled women in order to protect the ,purity of the race“? 


\subsection{Other "legitimate aims"}

At this point I would like to point out eugenic, social and economic reasons for involuntary treatment. These reasons to treatment do not seek the therapeutic benefit for a patient, but rather fulfil various ,,social interests“. Is it therefore acceptable from a human rights perspective to perform treatment influenced by these reasons on a patient without his consent? I put the title of this chapter into quotation marks, because I have my doubts, whether the following aims are legitimate.

Medical law is difficult and comprehensive system of rules, principles, ideas, difficult ethical issues and many ambiguous terms (best interest, consent, welfare, etc.). For this reason, physicians and patients are often confused and sometimes we can see a huge gap between law and the medical practice. Therefore, it is not surprising, that there are many interpretations of the ambiguous terms (for example, what the term „best interest“, means) and there is permanent risk of ill-treatment.

The reasons for involuntary treatment are frequently masked as therapeutic reasons and involuntary medical interventions are presented as a medical necessity for the protection the health of a patient himself or the health of other people. Frequent cases of such „masking“ are misuses of psychiatric medication. The European Committee for the Prevention of Torture (hereinafter referred as "CPT") as well as Czech National Preventive Mechanism (hereinafter referred as "NPM") constantly refers to misuse of psychiatric medication in health care facilities. ${ }^{17}$ Czech NPM revealed misuse of sedative effect of the psychiatric medication which was administered in order to ease work for the nursing staff. Bartlett also makes a short note about the relation between adequate staffing and sedative property of a medication. He argues that if "sedative property of a drug was the motivation for its use, it could be argued to constitute restraint, raising issues under Article 3." "The misuse of psychiatric medication that has no therapeutic purpose for a patient and seeks other purposes (for example to ease work for the staff) is highly risky for the health of a patient and thus reprehensible. However history shows, that even very intrusive medical interventions, which sought perverse goals were masked by therapeutic needs of a patient or others. For this reason I will make a few comments on the „non-therapeutic“ reasons for medical interventions.

\subsubsection{Eugenic reasons}

It would be difficult to find darker period of involuntary medical treatment in history, than that during the eugenic movement of the last century. ${ }^{19}$ The supporters of eugenics believed, that promotion of a „better (child)birth“ at the expense of ,worst (child)birth“ will lead to the improvement of human race and will make an end to the degeneration of society, that was caused by natural selection. ${ }^{20}$ Dolej si $^{21}$ has divided eugenics into positive and negative. Positive eugenics focuses on the reproduction of healthy and strong individuals ${ }^{22}$, while negative eugenics seeks to eliminate those, whose are the „burden“ to social progress. This „elimination“ was done, besides other measures ${ }^{23}$, by medical tools.

Examples of typical eugenic medical interventions are involuntary sterilization ${ }^{24}$, castration ${ }^{25}$, abortion ${ }^{26}$ and euthanasia $^{27}$. All these involuntary and often violent „reproductive interventions“ had only one goal - to prevent the "defective individuals" in spreading their „harmful genes“ and thus burdened the society.

Eugenic justification of medical treatment did not disappear with the end of the Second World War, but had continued, for example, as I know, in Sweden and Czechoslovakia ${ }^{28}$. The contemporary eugenic ideas in medicine have different appearance but are still present.

I can mention China's Maternal and Infant Health Care $\mathrm{Act}^{29}$ apparently adopted in response to enormous population pressure, that drive physicians to provide medical advice on long-term contraception or sterilisation to couples, which have been diagnosed with unspecified genetic disease of a serious nature after a mandatory pre-marital medical examination (PMME). ${ }^{30}$ Bobrow considers this law as clearly eugenic and argues, that (the law) ,pays scant heed to the niceties of informed consent so important to most medical geneticists "31.

Current eugenic questions arise concerning research. Especially research on human embryos and research relating to gene testing. The Unesco International Bioethic Committee on Ethical Aspects of Human Embryonic Stem Cell Research report sets forth, that ,the medical applications of embryonic stem cell research must be well-identified therapeutic applications and not trivial or cosmetic non-medical desires, nor a fortiori for eugenic enhancement ${ }^{\text {“32 }}$. The EU Charter of Fundamental Rights in Article 3 paragraph 2 sets forth, that ,in the fields of medicine and biology the prohibition of eugenic practices, in particular those aiming at the selection of 
persons, must be respected. " At this point, please have a look at the Chinese BGI Cognitive Genomics Project that focuses on genome testing in order to maximize the intelligence of new generations. ${ }^{33}$

In connection with the progress in gene testing, Bobrow argues, that ,the early commonplace observation that human genetic advances pose virtually no qualitatively new ethical questions, but display old questions in particularly stark light, remains true. ${ }^{\text {'34 }}$ From my perspective it is highly improbable, that countries will enact law that explicitly legalizes involuntary eugenic treatment. I therefore completely agree with the idea, that the difference between modern genetic (eugenic) technologies and the historical use of eugenics is a requirement of consent. „Today, individuals pursue genetic testing by choice. An individual can never be forced into testing or be required to take action, such as sterilization, based on the results of a genetic test. " 35 However, I have my concerns about eugenic influence in scientific progress relating to genes and indirect (hidden) eugenic pressure to autonomy of will of a patient.

\subsubsection{Social Interests}

Justification of involuntary medical interventions by social reasons is very often closely tied to economic or eugenic reasons. Involuntary medical interventions are then undergone for the purpose of protecting social welfare of a patient, his/her family or the whole society. The best example of such kind of intervention is forced sterilisation of women with disability. I have mentioned above the risk of vague term ,the patient's best interest" or "the patient's welfare" and I have to emphasize it again at this point. I will mention two judgements, which deal with forced sterilisation of women with serious mental disability justified by the ,best interest“.

The first case is Re Eve ${ }^{36}$ in which the Supreme Court of Canada held that the best interest of a person should be interpreted as a protection of health and life of a person, not protection against possible difficulties with upbringing a child. Furthermore the court made a statement that the benefits of a non-therapeutic sterilization are disputable and cannot be compared to the physical harm of a person.

On the other hand in a case $\operatorname{Re} \mathrm{B}^{37}$ the House of Lords did not agree with the above mentioned perception of the best interest of a person and concluded, that term best interest contains also protection against unwanted pregnancy and delivery. Court furthermore argued, that women with serious mental disorder is not able to understand the consequences of pregnancy and delivery, so it can cause her stress and psychological suffering and also has no benefits for the new-born. ${ }^{38}$ Justice Lord Hailsham argued that it is completely absurd to talk about basic reproductive rights of an individual who is unable to understand the causal link between sexual intercourse and childbirth, the essence of pregnancy, childbirth context and is unable to exhibit maternal instincts or bring up a child. ${ }^{39}$

In Re B court did not accept the distinction between therapeutic and non-therapeutic aspects of sterilization and the only one criterion for sterilization, in the opinion of the court, should be the best interest of a person. And the best interest is interpreted in a way that covers various social aspects of life of a person. I have my concerns, that extensive concept of the best interest will lead to the protection of social welfare of family members of a disabled women, the interests of people caring for the patient, other members of society, social security funds, etc.

I have to emphasize, that social (as well as eugenic) justification of involuntary medical treatment does not represent the official approach in medical law. In decision of Court of Appeal of a case $\operatorname{Re} \mathrm{A}^{40}$ was argued, that „social reasons for carrying out of non-therapeutic invasive surgery is not part of the present state of the law. With the direct application of the European Convention on Human Rights to English domestic law imminent, the courts should be slow to take any step which might infringe the rights of those unable to speak for themselves."

The danger of involuntary medical intervention based on social grounds lies in the extensive and ambiguous perception of the term ,best interest" and the narrow borders between therapeutic and non-therapeutic reasons.

\subsubsection{Economic wellbeing}

One can argue, as pointed out above, that interruption or sterilization of disabled women, who is not able to carry out the duties of motherhood, is justified in the interest of these women, child, nursing staff and also the state budget. The castration of sexual offender can be also seen as cheaper solution, than his indefinite detention in psychiatric hospital with all conceivable expenses on medical care. At this point I would like to make a few comments on euthanasia. 
There is no doubt, that euthanasia of terminally and seriously ill patient saves expenditures on a hospital bed that can be used for more "promising" patient. There is no doubt that euthanasia takes off the strain on family members $^{41}$ and social welfare. To sum up, euthanasia of one hopeless person save money, that can be more effectively allocated elsewhere. Battin argues that doctors may not want to waste time on expensive and timeconsuming medical procedures and may encourage patients to agree to euthanasia. ${ }^{42}$

I do not identify with the aforesaid economic approach to euthanasia, but some do. For example Charlie Sprague argues, that ,those with terminal illnesses are resource sinks for society. End of life care is incredibly expensive due to the frequency of hospitalizations, the increased need for specialists' attention, etc. Those with terminal illnesses have even more expensive health care needs. Obviously, those in the final stages of a terminal illness are no longer in any position to contribute economically to society. Their continued existence may be personally meaningful to those who love them, but from an economic perspective they are all cost and no benefit. "“3

My view is that euthanasia goes against the principle "primum non nocere" that arises from the Hippocratic Oath, because the doctors do not cure patient, but terminate his life and thus cause the most serious harm to a patient - death. Autonomy of the will has its limits. It cannot be interpreted in a way, that patient has the right to decide to be injured or killed. ${ }^{44}$

\section{Criterion of medical necessity}

Limitation of the right to physical integrity must fulfil the criterion of necessity in democratic society and must be proportionate. ${ }^{45}$

The ECHR deals with the question of the necessity in the case Dudgeon v. United Kingdom, where the ECHR stated as follows: "Firstly, "necessary" in this context does not have the flexibility of such expressions as "useful", "reasonable", or "desirable", but implies the existence of a "pressing social need" for the interference in question. " ${ }^{46}$ In the judgement Ollson v. Sweden, ECHR stated, that ,, the notion of necessity implies that the interference corresponds to a pressing social need and, in particular, that it is proportionate to the legitimate aim pursued. "

All involuntary interventions into physical integrity of a patient must respond to the actual threat to the health of the patient or others, in words of ECHR, it must correspond to a pressing social need. The intervention must also be proportionate to the „legitimate aim pursued". Herring gives an example: "If a terrible disease were to take a grip on the population, threatening to kill thousands of people, it is not difficult to believe that the court would permit the taking of blood from a person who appeared to have an antibody. Also, perhaps, if in order to a save another person's life, a very minor invasion of another person were required (such as the taking of a hair), a court might be tempted to authorize it. ${ }^{47}$

When there is no sufficient evidence that the necessity criterion is fulfilled, the principle "in favorem libertatis" should be applied.

\section{Conclusion}

The fundamental right to physical integrity of a person is very „fragile“ right. People with mental disabilities, elderly people, minors or people restricted in their liberty are particularly vulnerable. One of the most important roles of contemporary democratic legal state is to protect, respect and fulfil the fundamental human rights and freedoms of every human being.

The reality is that state has much more interests, than mere protection of human rights. I have mentioned social, economic and eugenic interests and pointed out particular medical interventions that are or were performed in order to fulfil some of these interests. From the famous decision Buck v. Bell has been passed nearly 90 years, but is the contemporary law and medicine different? At least Article 2 of the Oviedo Convention sets forth different attitude to relationship between state and the human ${ }^{48}$. My point of view is that an involuntary intervention into the physical integrity of a patient may only be carried out, when it is necessary in order to protect his or her health or health of other people. Any other reasons should not be acceptable. 


\section{References}

[1] Please see more about the term „hard case“ and its definition in: PATTERSON, Denis. Law and Truth. Oxford: Oxford University Press. 1996, p. 88.

[2] X and Y v. Netherlands, Application No. 8978/80, judgment 26 March, para 22. Benderskiy v. Ukraine, Application No. 22750/02, judgment 15 November 2007, para 59.

[3] V. C. v. Slovakia, Application No. 18968/07, judgment 8 November 2011, para 144.

[4] Y. F. v. Turkey, Application No. 24209/94, judgment 22 July 2003, para 33.

[5] BARAK, Aharon. Human Dignity - The Constitutional Value and the Constitutional Right. Cambridge: Cambridge University Press. 2015, p. 237.

[6] BARAK, Aharon. Human Dignity - The Constitutional Value and the Constitutional Right. Cambridge: Cambridge University Press. 2015, s. 347. p. 144.

[7] The importance of fundamental right is a significant aspect that ECHR takes into account when assessing the criterion of "necessity in a democratic society".

[8] Please see involuntary sterilization case V. C. v. Slovakia, Application No. 18968/07, judgment 8 November 2011.

[9] "An intervention in the health field may only be carried out after the person concerned has given free and informed consent to it."

[10] Please see standards on treatment with such vulnerable people. For example CPT standards, UN Standard Minimum Rules for the Treatment of Prisoners, UK Her Majesty's Inspectorate of Prisons Expectations, etc.

[11] The Committee on Economic, Social and Cultural Rights (CESCR). General Comment No. 14: The Right to the Highest Attainable Standard of Health (Art. 12), point 34 [online]. Available from: http://www.ohchr.org/Documents/Issues/Women/WRGS/Health/GC14.pdf.

[12] European Committee for the Prevention of Torture and Inhuman or Degrading Treatment or Punishment (CPT). CPT standards, $§ 41$.

[13] Hospice Patients Alliance. Hippocratic Oath [online]. Available from: http://www.hospicepatients.org/hippocraticoath.html.

[14]HERRING Jonathan. The medical law and ethics. Oxford: Oxford University Press., 2014. p. 27.

[15] HERRING Jonathan. The medical law and ethics. Oxford: Oxford University Press., 2014. p. 28.

[16]Please read more about paternalistic care in: HERRING Jonathan. The medical law and ethics. Oxford: Oxford University Press., 2014.

[17]For more information please see: European Committee for the Prevention of Torture and Inhuman or Degrading Treatment or Punishment (CPT). CPT standards, p. 60 [online]. Available from: http://www.cpt.coe.int/en/documents/eng-standards.pdf. Public Defender of Rights. Protection Against Ill-treatment Report on the Activities of the Public Defender of Rights as the National Preventive Mechanism, p. 17 [online]. Available from: http://www.ochrance.cz/fileadmin/user_upload/ochrana_osob/Zpravy-vyrocni/2014-NPM-AnnualReport.pdf.

[18]BARTLETT, Peter, OLIVER, Levis, OLIVER, Thorold. Mental disability and the European Convention on Human Rights. Leiden: Martinus Nijhoff Publishers., 2007. p. 119.

[19] For more information about eugenics, please see: Genetic generation. Introduction to Eugenics [online]. Available from: http://knowgenetics.org/history-of-eugenics/.

[20] Please see The Origin of Species by Charles Darwin.

[21]DOLEJŠÍ, Zbyněk. Eugenics - how to improve the hereditary potential of the society? [online]. Brno: Masaryk University, 2006. Available from: http://is.muni.cz/el/1431/jaro2008/Bi6170/um/Eugenika.pdf.

[22] For example in Nazi Germany, the "good couples“ were supported to have a children and were penalised for undergoing an interruption.

[23] Various systems of financial benefits and penalties.

[24] In January 1934 the sterilization act in Germany came into force and in the same year sterilization act was adopted also in Norway and Sweden. A year after the sterilization act was adopted in Finland. Then also in Denmark, Switzerland, Austria, Estonia and France. 
[25]Dolejší states, that involuntary castration was legalized only in Finland between 1929 - 1967 and relates only to sexual deviants. Countries like Germany, Norway, Finland, Iceland, Sweden and Switzerland legalized castration only as an alternative to imprisonment. In: DOLEJŠ́́, Zbyněk. Eugenics - how to improve the hereditary potential of the society? [online]. Brno: Masaryk University, $2006 . \quad$ Available from: http://is.muni.cz/el/1431/jaro2008/Bi6170/um/Eugenika.pdf.

[26] Please see eugenic abortions in Denmark during 1934 - 1950.

[27] See more for example in connection with the Euthanasia Society of America (established in 1938) or Nazi euthanasia programmes.

[28] Statistics consistently shows that approximately 60.000 people were sterilized in Sweden during 1935-1976. Also Czechoslovakia sterilization of Roma women has continued throughout the communist era.

[29] The Law of the People's Republic of China on the Maternal and Infant Health Care (MIHCL).

[30] GUO, Sun-Wei. China: The Maternal and Infant Health Care Law. [online]. Available from: http://www.els.net/WileyCDA/ElsArticle/refId-a0005201.html.

[31] BOBROW, Martin. Redrafted Chinese law remains eugenic. Medical Genetic. 1995 Jun; 32(6). [online]. Available from: http://www.ncbi.nlm.nih.gov/pmc/articles/PMC1050477/?page=1.

[32] Unesco International Bioethic Committee on Ethical Aspects of Human Embryonic Stem Cell Research. The Report on Use of Embryonic Stem Cells in Therapeutic Research Report. 2001, p. 12. [online]. Available from: http://www.eubios.info/UNESCO/ibc2001sc.pdf.

[33]For more information please see: MILLER, Geofrey. 2013: What *should* we be worried about? Chinese eugenics. [online]. Available from: https://edge.org/response-detail/23838.

[34]BOBROW, Martin. Redrafted Chinese law remains eugenic. Medical Genetic. 1995 Jun; 32(6). [online]. Available from: http://www.ncbi.nlm.nih.gov/pmc/articles/PMC1050477/?page=1.

[35] Genetic generation. Is Eugenics Happening Today? [online]. Available from: http://knowgenetics.org/is-eugenicshappening-today/.

[36] Judgement of the Supreme Court of Canada. E (Mrs) v Eve, [1986] 2 S.C.R. 388.

[37] Judgement of the House of Lords of United Kingdom of Great Britain and Northern Ireland in a case of Re B (1988) AC 199.

[38] DAVIES. Michael. Textbook on Medical Law. London: Blackstone Press Limited, 1996.

[39] DAVIES. Michael. Textbook on Medical Law. London: Blackstone Press Limited, 1996.

[40] COURT OF APPEAL (CIVIL DIVISION) [2000] 1 FLR 549, [2000] 1 FCR 193

[41] HERRING Jonathan. The medical law and ethics. Oxford: Oxford University Press., 2014. p. 541.

[42] HERRING Jonathan. The medical law and ethics. Oxford: Oxford University Press., 2014. p. 537.

[43]SPRAGUE, Charlie. The Economic Argument for Euthanasia. 2009. Available from: http://cmcforum.com/opinion/06082009-the-economic-argument-for-euthanasia.

[44] KA and AD v. Belgium, Application No. 42758/98, judgment 17 February.

[45] Cumpănă and Mazăre v. Romania, Application No. 33348/96, Judgment 17 December 2004.

[46] Kmec, J., Kosař, D., Kratochvíl, J., Bobek, M. Europen convention on human rights. Commentary. 1. ed. Praha: C. H. Beck, 2012, p. 884.

[47] HERRING Jonathan. The medical law and ethics. Oxford: Oxford University Press., 2014. p. 173.

[48] This provision sets forth, that: ,the interests and welfare of the human being shall prevail over the sole interest of society or science." 